\author{
V. Naddachyn, Odessa, Ukraine
}

\title{
RELATIONSHIP BETWEEN PROCESSING TEMPERATURE AND INTERRUPTION IN THE GRINDING PROCESS
}

\begin{abstract}
Annotation. This article discusses issues related to the processing of grinding wheels with an intermittent working surface and their influence on the grinding process. To solve this problem, it was necessary to first identify the relationship between the discontinuity of the process and the shock load. Next, determine the trajectory of movement of the forming point of the circle. A diagram of the movement of the center of mass of the circle and the forces acting on it is constructed. Equations are derived that determine these displacements. A system of equations describing the movement of the spindle axis under the action of cutting forces and power imbalance of the wheel is presented. The relationship between the frequency, amplitude of forced vibrations and displacements of the axis under the action of a harmonic disturbing force has been established. Theoretical calculations are confirmed by practical results. Based on the movement of the forming point of the circle, the parameters of the profile of the machined surface are set. The influence of the discontinuity of the process on the grinding temperature is considered.
\end{abstract}

Keywords. Intermittent grinding; vibrations during grinding; trajectory of movement; hit; surface profile; grinding temperatures

One of the ways to improve the technical level and quality of products is to improve existing technological processes, incl. and grinding.

It is known that the operational properties of machine parts depend not only on the accuracy of their manufacture, but also on the high quality of surfaces achieved in the final machining operations - grinding operations.

At the same time, one of the most common defects in these operations can be burned surfaces and, as a result, a violation of the structure and physical and mechanical properties of the surface layer. The solution to this problem is possible:

1) By reducing the grinding modes, and, consequently, the processing efficiency.

2) The use of new technological methods of processing, in particular, an abrasive tool with an intermittent working surface.

Discontinuous circles can be directly attributed to this type of tool design (a description of the design and technological capabilities are given in numerous works of Prof. A.V. Yakimov and his students, composite wheels, segment grinding wheels.

However, the use of this type of abrasive tool is constrained by the presence of tool vibrations (caused by the impact of the protrusion at the moment of contact with the workpiece), the possibility of waviness and unsatisfactory roughness on the work surface. 
For purposeful control of these parameters during intermittent grinding, it was necessary to identify how waviness is formed on the treated surface, as well as to determine the relationship of the formed waviness with the design of the intermittent circle, its oscillations, processing modes and temperature dependences.

It is known that during grinding there are certain possibilities to control the quality parameters of the processed surface. But for an effective solution to this process, you need to know the reasons affecting these parameters.

The process of forming geometric parameters, in particular, roughness and waviness on the processing surface.

Basically, the works deal with the formation of roughness [1, etc.]. Conditions conducive to the appearance of waviness are rarely considered [2, 3].

The choice of the optimal parameters of waviness and roughness is proposed to be made based on the service purpose of the part and the corresponding operating conditions of the friction pairs.

The relationship between the parameters of the shock load and the amplitude of forced vibrations with the design of the grinding wheel.

As noted above, the oscillation parameters of the grinding wheel-spindle system, its amplitude and frequency, are a consequence of the impact of the shock load arising from grinding with intermittent wheels. The carried out experiments also found that the repetition rate of shock pulses depends on the number of protrusions and the speed of rotation of the circle. For example, for a circle with a diameter of $\varnothing 250 \mathrm{~mm}$ and with a constant rotation speed $\mathrm{n} \approx 3000 \mathrm{rev} / \mathrm{m}$, the frequency of additional forced oscillations will be: $f=182 \ldots 546 \mathrm{~Hz}$; (for circles with 4 ... 12 lugs)).

This is clearly confirmed by the oscillograms of the shock load (Fig. 1). With a change in the number of protrusions, the repetition time of shock pulses also changes, and with a change in the design of the circle (intermittent or compositional), the amplitude of the shock load changes.

The action of the shock load accordingly causes the grinding wheel to vibrate with a certain amplitude and frequency. The magnitude of the vibration amplitude is also influenced by the processing modes.

With an increase in the table speed, the relative speed of collision of the cutting edge of the tool with the workpiece surface [4] increases, the impulse of the force and the kinetic energy of the colliding bodies, depending on the speed (f. 1).

$$
E_{0}=\frac{M \cdot V_{0}^{2}}{2} \text {. }
$$


At the same time, due to the closed nature of the "cutting process - EES" system, the change in the kinetic energy of impact $\left(E_{0}\right)$, according to dependence (2)
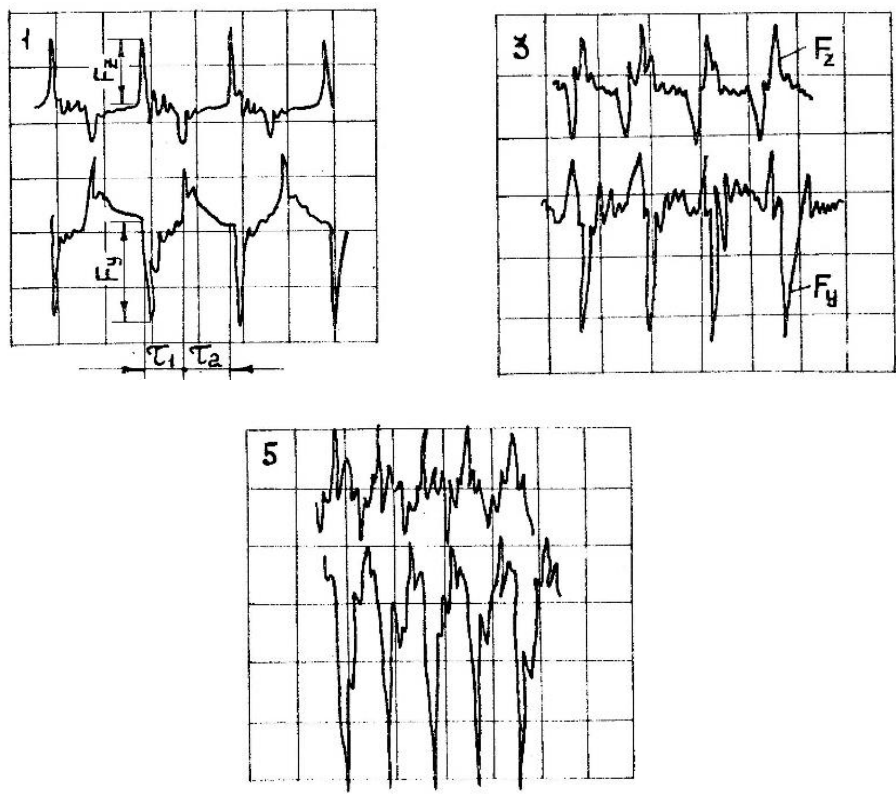

Figure 1 - Changes in the repetition rate of the shock load and its amplitude from the structure of the circle.

( 1 - broken circle with 2 protrusions (at $V_{d}=0.17 \mathrm{~m} / \mathrm{s}, t=1010^{-6} \mathrm{~m}$, gain $F_{z}=1 \mathrm{~V} / \mathrm{div}$, $F_{y}=2 \mathrm{~V} /$ div); 3 - circle with $\mathrm{n}=8$ pcs.; 5 - circle with $\mathrm{n}=12$ pcs. (at $V_{d}=0.3 \mathrm{~m} / \mathrm{s}, t=5010^{-6} \mathrm{~m}$, gain $\left.F_{z}\left(F_{y}\right)=5 \mathrm{~V} / \mathrm{div}\right)$ )

$$
A^{2}=\frac{2 \cdot E_{0}}{m \omega^{2}}
$$

causes a change in the amplitude of oscillations $(A)$ [4].

Therefore, it is necessary to determine the magnitude of the vibration amplitude caused by the shock load, as well as the trajectory of the displacement of the center of the circle and the "forming point".

It is known that the trajectory of the grinding wheel is a complex closed cycloidal or quasi-cycloidal curve.

First, consider the trajectory of the axis of the grinding wheel in the presence of imbalance. Then, the imbalance of the spindle assembly can be represented in 
the form of: structural imbalance $\left(\overline{q_{k}}\right)$ (for example, a violation of the symmetry of the location of the projections and depressions of the circle); technological $\left(\overline{q_{\mathrm{T}}}\right)$ (associated with a certain tolerance in the manufacture of elements of the spindle assembly, assembly inaccuracy, etc.); operational $\left(\overline{q_{3}}\right)$ (associated with a change in the size of the grinding wheel during processing and a shift in its center of mass due to the uneven density of its material). That is, representing as the main vector of unbalanced forces $(\bar{Q})(3)$.

$$
\bar{Q}=\overline{q_{\mathrm{T}}}+\overline{q_{k}}+\overline{q_{3}}
$$

These imbalances will cause low-frequency oscillations (let's call them the carrier (fundamental) frequency) of the "grinding wheel - spindle" system, the amplitude of which depends on the value of the displacement of the center of mass of the grinding wheel $A_{0}=f(E)$, (that is, its imbalance), and vibration frequency from the angular speed of rotation of the spindle $\omega=f\left(n_{\text {rev }}\right)$. When additional counterbalancing forces are introduced into the system, opposite in sign, the main vector of unbalanced forces can be reduced to the minimum permissible, in terms of technological capabilities. That is, by balancing the grinding wheel or the spindle unit as a whole.

$$
\bar{Q}=-\bar{Q}_{\mathrm{m}} \rightarrow \min
$$

Taking into account additional forced vibrations, associated with the specific features of grinding with these wheels, we will compose a differential equation of motion of the center of mass of the wheel and the relative rotations of the spindle axis about the center of mass.

Let's make a number of assumptions:

1). When recording an oscillogram during grinding, oscillations are clearly visible associated with the presence of cutting forces and imbalance of the wheel, the frequency of which corresponds to the spindle rotation speed, with the superposition of a higher order harmonic on the fundamental component, caused by the action of impact forces $F_{v}$, the frequency of which corresponds to the frequency of change of these forces (the number of protrusions on the circle) (Fig. $2,3)$.

That is, system vibrations will occur due to imbalance of the grinding wheel and impact forces caused by the intermittent cutting process.

2). There is no damping in an elastic technological system.

3). Studies carried out on a surface grinding machine (type 3G71) showed that the rigidity of the magnetic table, and, consequently, of the part installed on it, 
is approximately 2 orders of magnitude higher than the rigidity of the spindle supports. That is, it is assumed that the part has absolute rigidity and table vibrations can be ignored.

4). The spindle of the machine, together with the grinding wheel, is considered rigid, mounted on flexible supports, since the bending stiffness of the spindle significantly exceeds the stiffness of the supports.

5). The spindle axis is aligned with the geometric center of the circle.

Let's find the equation of motion of the circle, taking into account its imbalance.

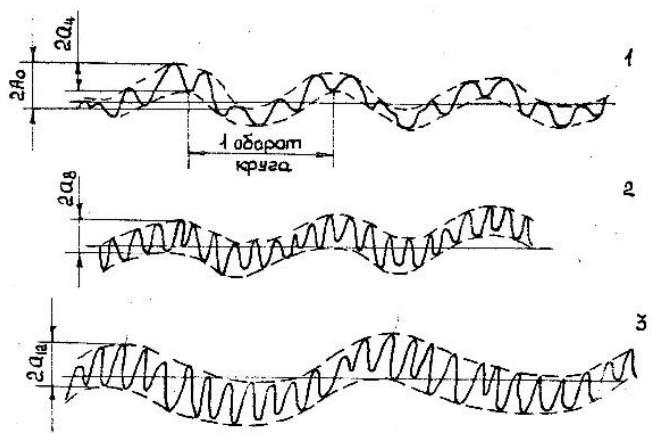

Figure 2 - Sample vibration displacement recording

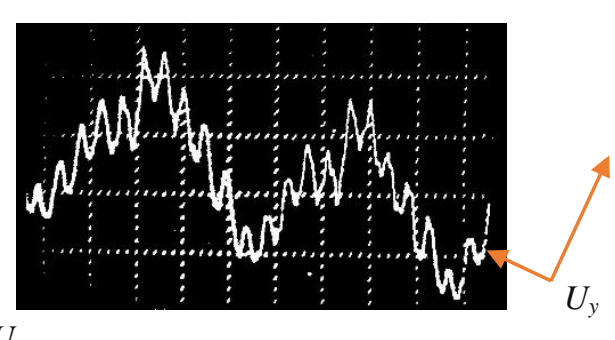

a)

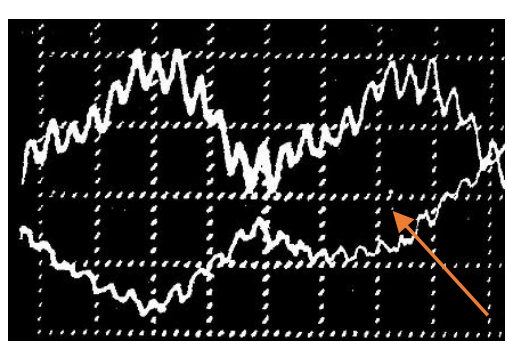

b)

Figure 3 - Oscillograms of vibration displacements (a) sweep (circle with 4 protrusions); (b) with 12 projections

Let $y_{1}, y_{2}, z_{1}, z_{2}$ represent small displacements of the spindle axis in the supports during vibrations in the radial and tangential directions (on the 1st and 2nd supports, respectively) (Fig. 4). 
We find the displacement of the center $\mathrm{C}$ of the grinding wheel mass through the movement of the spindle in the supports (Fig. 5) (in the vertical and horizontal planes).

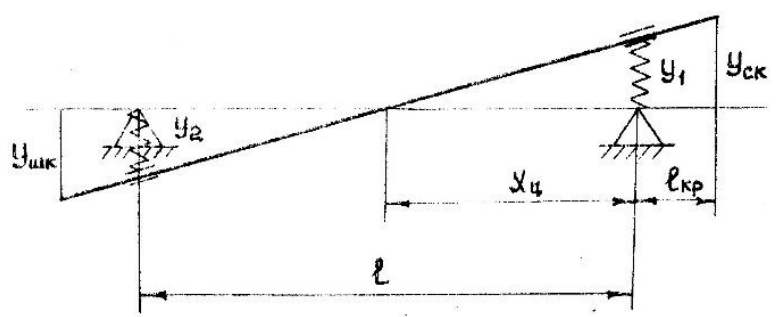

Figure 4 - Diagram of the radial movement $y_{c \kappa}$ of the center of mass of the grinding wheel depending on the movement of the spindle axis in the supports

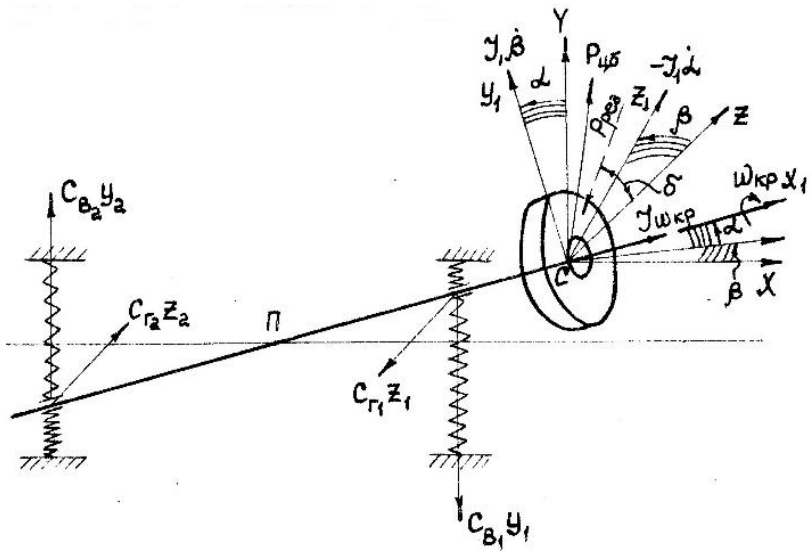

Figure 5 - Scheme of the acting forces of an unbalanced cantilever spindle with a grinding wheel

$$
y_{\text {ск } 1}=y_{1} \cdot \frac{l_{\text {кр }}+x_{\text {ц }}}{x_{\text {ц }}}, \quad z_{\text {ск1 }}=z_{1} \cdot \frac{l_{\text {Кр }}+x_{\text {Ц }}}{x_{\text {ц }}},
$$

where $x_{\text {ц }}-$ is the point of intersection of the beam axis with the horizontal line under equilibrium conditions.

Let's designate $C_{61}, C_{62}, C_{21}, C_{22}$ stiffness of supports. Bearing reactions in the $\mathrm{Y}$ and $\mathrm{Z}$ directions caused by small displacements $y_{1}, y_{2}, z_{1}, z_{2}$, will be $C_{61} \cdot y_{1}$, 
$C_{62} \cdot y_{2}, C_{21} \cdot z_{1}, C_{22} \cdot z_{2}$. The disturbing factors for an ordinary circle, taking into account its imbalance, will be the cutting force $\mathrm{P}_{\text {peз }}$ and the unbalanced centrifugal force $\mathrm{P}_{\text {ц.б. }}$ (fig. 5).

The equation that determines the displacement of the center of mass in projections on the $\mathrm{Y}$ and $\mathrm{Z}$ axes has the form (4)

$$
\left.\begin{array}{l}
\frac{P}{g} \cdot \ddot{y}_{\mathrm{cK}}+C_{\mathrm{E} 1} \cdot y_{1}-C_{\mathrm{B} 2} \cdot y_{2}+P_{\mathrm{pes}} \cdot \sin \delta+P=P_{\mathrm{L}, 6 .} \cdot \sin \omega_{\mathrm{Kp}} t ; \\
\frac{P}{g} \cdot \ddot{z}_{\mathrm{cK}}+C_{\mathrm{r} 1} \cdot z_{1}-C_{\mathrm{r} 2} \cdot z_{2}+P_{\mathrm{pes}} \cdot \cos \delta=P_{\mathrm{L}, 6.6} \cdot \cos \omega_{\mathrm{Kp}} t,
\end{array}\right\}
$$

where $P-$ is the force of gravity.

To fully determine the movement of the spindle axis, it is necessary to compose differential equations describing the rotations of the spindle axis $x_{I}$ relative to the fixed axes $\mathrm{X}$ and $\mathrm{Z}$. According to the law of change in the angular momentum, the time derivative of the total angular momentum of a moving system about a fixed axis is equal to the moment of forces about the same axis. As a result of elastic deformations, the axis of rotation $x_{I}$ makes small angles $\alpha$ and $\beta$ with the fixed coordinate planes $\mathrm{XY}$ and $\mathrm{XZ}$. The angles of rotation of the spindle axis in the vertical and horizontal planes through the movement of the spindle in the supports will be

$$
\propto=\frac{y_{2}-y_{1}}{l} ; \quad \beta=\frac{z_{2}-z_{1}}{l} .
$$

The components of the angular momentum about the axes $x_{1}, y_{1}, z_{1}$ are determined

$$
L_{x 1}=-I \cdot \omega_{\mathrm{Kp}} ; \quad L_{y 1}=-I_{1} \cdot \tilde{\beta} ; \quad L_{z 1}=I_{1} \cdot \tilde{\propto}_{a}
$$

where $I$ - is the moment of inertia of the grinding wheel relative to the $x_{I}$ axis; $I_{1}$ - moment of inertia of the grinding wheel relative to the axes $o y_{1}$ and $o z_{1}$.

We find the angular momentum relative to the fixed axes $\mathrm{X}$ and $\mathrm{Z}$ by designing the moments $L_{x 1} ; L_{y 1} ; L_{z 1}$ on these axes.

$$
\begin{aligned}
& L_{Y}=L_{y 1}+L_{x 1} \times \propto=-I_{1} \times \dot{\beta}-I \times \omega_{\mathrm{kp}} \times \propto ; \\
& L_{z}=L_{z 1}+L_{x 1} \times \beta=-I_{1} \times \dot{\alpha}-I \times \omega_{\mathrm{kp}} * \beta .
\end{aligned}
$$

Based on the law of changing the amount of motion, the moments of external forces are defined as (6) 


$$
M_{Y}=\frac{d}{d t} L_{Y} ; \quad M_{Z}=\frac{d}{d t} L_{Z}
$$

Taking into account (5) and (6) the differential equations describing the rotations of the spindle axis can be written

$$
\begin{gathered}
M_{Z}+C_{\mathrm{B} 1} \times y_{1} \times l_{\mathrm{Kp}}-C_{\mathrm{B} 2} \times y_{2} \times\left(l+l_{\mathrm{Kp}}\right)=0 ; \\
M_{Y}-C_{\mathrm{r} 1} \times z_{1} \times l_{\mathrm{Kp}}+C_{\mathrm{r} 2} \times z_{2} \times\left(l+l_{\mathrm{Kp}}\right)=0
\end{gathered} \mid .
$$

The system of differential equations describing the movement of the spindle axis of the grinding wheel in space under the action of cutting forces and imbalance of the wheel has the form (8):

$$
\begin{aligned}
& \frac{P}{g} \cdot\left(\ddot{y}_{1} \cdot \frac{l_{\mathrm{kp}}+x_{\mathrm{L}}}{x_{\mathrm{L}}}\right)+C_{\mathrm{E} 1} \cdot y_{1}-C_{\mathrm{B} 2} \cdot y_{2}+P_{\mathrm{pes}} \cdot \sin \delta+P=P_{\text {ц, } 6 .} \cdot \sin \omega_{\mathrm{Kp}} t ; \\
& \frac{P}{g} \cdot\left(\ddot{z}_{1} \cdot \frac{l_{\mathrm{kp}}+x_{\mathrm{L}}}{x_{\mathrm{L}}}\right)+C_{\mathrm{r} 1} \cdot z_{1}-C_{\mathrm{r} 2} \cdot z_{2}+P_{\mathrm{pes}} \cdot \cos \delta=P_{\text {ц.6. }} \cdot \cos \omega_{\mathrm{Kp}} t ; \\
& I_{1} \cdot \frac{\ddot{y}_{2}-\ddot{y}_{1}}{l}+I \cdot \omega_{\mathrm{Kp}} \cdot \frac{\dot{z}_{1}-\dot{z}_{2}}{l}+C_{\mathrm{E} 1} \cdot y_{1} \cdot l_{\mathrm{Kp}}-C_{\mathrm{B} 2} \cdot y_{2} \cdot\left(l+l_{\mathrm{Kp}}\right)=0 \text {; } \\
& I_{1} \cdot \frac{\ddot{z}_{1}-\ddot{z}_{2}}{l}+I \cdot \omega_{\mathrm{kp}} \cdot \frac{\dot{y}_{1}-\dot{y}_{2}}{l}-C_{\mathrm{r} 1} \cdot z_{1} \cdot l_{\mathrm{kp}}+C_{\mathrm{r} 2} \cdot z_{2} \cdot\left(l+l_{\mathrm{kp}}\right)=0 . \quad
\end{aligned}
$$

The system of equations (8) is compiled for the power imbalance of the circle, at which the vibration amplitude is $2 \ldots 3$ times greater than the vibration amplitude caused by momentary imbalance.

In the presence of gyroscopic moments, vibrations in the YOX and ZOX planes are interconnected, that is, plane vibrations of the shaft are impossible and represent "direct" precession with an angular velocity equal to the spindle rotation speed.

A particular solution of the system of differential equations (8), which are oscillations of a spindle with a circle under the action of cutting forces and the presence of an imbalance, has the form (9)

$$
\begin{array}{ll}
y_{1}=y_{10}+B_{1} \cdot \sin \omega_{\mathrm{kp}} t ; & y_{2}=y_{20}+B_{2} \cdot \sin \omega_{\mathrm{\kappa p}} t ; \\
z_{1}=z_{10}+A_{1} \cdot \cos \omega_{\mathrm{kp}} t ; & z_{2}=z_{20}+A_{2} \cdot \cos \omega_{\mathrm{\kappa p}} t
\end{array}
$$


where $y_{10^{\prime}} y_{20^{\prime}} z_{10}, z_{20}$ - are the displacements of the points of the spindle axis lying in the plane of the supports caused by the action of the cutting forces $P_{\text {pes }}$ and the gravity force of the circle $P$ (Fig. 6).

$A_{1}, A_{2}, B_{1}, B_{2}-$ vibration amplitudes of the grinding headstock supports (horizontal and vertical).

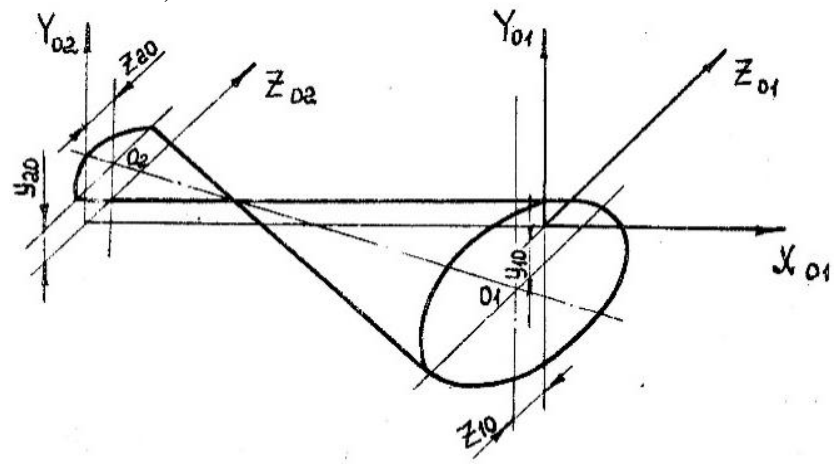

Figure 6 - Surface described by the spindle axis in space under the influence of imbalances of the grinding wheel

After transforming equations (9) and substituting in (8), taking into account the representation of the cutting force $P_{\text {pes }}$ in the form of a permanently acting force changing according to a sinusoidal law, and the force of gravity $P$ as a uniformly distributed mass over the entire volume of the circle, we find the determinants of the $\Delta$ system, and on the first support $\Delta A_{1}$, and $\Delta B_{1}$. And after excluding the parameter $t$ from equation (9), we obtain the canonical equations of ellipses (10) with the origin at the points $O_{1}\left(y_{10^{\prime}} z_{10}\right)$ and $O_{2}\left(y_{20^{\prime}} z_{20}\right)$, respectively.

$$
\begin{aligned}
& \frac{\left(y_{1}-y_{10}\right)^{2}}{B_{1}^{2}}+\frac{\left(z_{1}-z_{10}\right)^{2}}{A_{1}^{2}}=1 ; \\
& \frac{\left(y_{2}-y_{20}\right)^{2}}{B_{2}^{2}}+\frac{\left(z_{2}-z_{20}\right)^{2}}{A_{2}^{2}}=1 .
\end{aligned}
$$

Consequently, under the action of unbalanced forces, as a result of the addition of gyroscopic vibrations in the vertical and horizontal directions, the end of the spindle axis describes an elliptical trajectory. 
As studies have shown, on the main component of wheel vibrations (Fig.3a) associated with its imbalance, another harmonic of a higher order is superimposed, arising under the action of a disturbing force $F_{B}$ (i.e. shock load), associated with the specific conditions of processing these circles (Fig. 7).

Representing the disturbing force $F_{6}$ in the form of two components $F_{6 y}$ and $F_{6 z}$, expanding them in a Fourier series and considering certain harmonics, then

$$
\begin{aligned}
& F_{\text {вy }}=B \cdot \sin \omega_{1} t ; \\
& F_{\text {вz }}=A \cdot \sin \omega_{1} t
\end{aligned}
$$

where $A$ and $B$ are the amplitude values of the forces $F_{6 z}$ and $F_{\text {в }}$

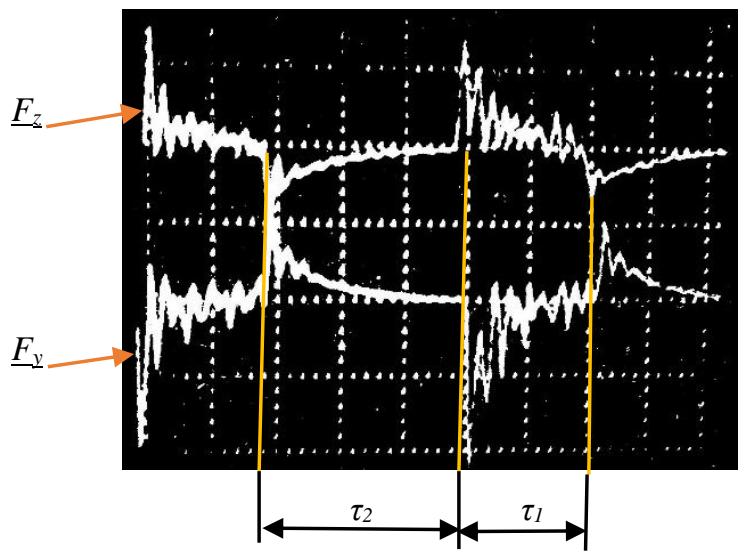

Figure 7 - Oscillograms of the shock load arising in the process of grinding ( $\tau_{1}-$ is the time of passage of the protrusion, $\tau_{2}-$ is the time of passage of the groove)

Equations of motion of the center of a circle under the action of a shock load in the $Y O Z$ plane

$$
\begin{aligned}
& \ddot{y}+\omega^{2} y=B \cdot \sin \omega_{1} t ; \\
& \ddot{z}+\omega^{2} z=A \cdot \sin \omega_{1} t .
\end{aligned}
$$

Making the appropriate transformations, we find the displacement of the axis under the action of a harmonic disturbing force $F_{B}$

$$
\begin{aligned}
& y^{*}=\frac{B}{\omega^{2}-\omega_{1}^{2}} \times \sin \omega_{1} t ; \\
& z^{*}=\frac{A}{\omega^{2}-\omega_{1}^{2}} \times \sin \omega_{1} t .
\end{aligned}
$$


That is, under the action of a harmonic disturbing force, the spindle axis relative to the ellipsoidal curve will also perform harmonic sinusoidal oscillations.

Thus, based on the principle of superposition when grinding with intermittent wheels, the center of mass of the wheel will describe in the section plane $Y O Z$, perpendicular to the spindle axis, a complex closed curve described by expression (13) which determines the position of the center of mass of the wheel at a given time $t_{c}$ relative to the fixed coordinates $O^{\prime} Y$ and $O^{\prime} Z$.

$$
\left.\begin{array}{l}
Y=B_{\mathrm{CB}}{ }^{*} \sin \omega_{0} t_{c}+U_{y} \cdot \sin \omega_{\mathrm{B}} t_{c} \cdot \sin \omega_{0} t_{c} ; \\
Z=A_{\mathrm{Cr}}{ }^{*} \cos \omega_{0} t_{c}+U_{z} \cdot \sin \omega_{\mathrm{B}} t_{c} \cdot \cos \omega_{0} t_{c}{ }^{\prime}
\end{array}\right\}
$$

where $A_{\mathrm{cr}}$ and $B_{\mathrm{cE}}$ - are the amplitudes of horizontal and vertical (respectively) oscillations associated with the imbalance of the circle;

$U_{y}$ and $U_{z}$ - are the amplitudes of forced radial and tangential oscillations associated with the action of the forced disturbing force;

$\omega_{0}$ and $\omega_{\mathrm{B}}-$ are the frequencies of the fundamental and high-frequency components of forced oscillations (respectively).

That is, a system of equations (13) was obtained, which determines the coordinates of the movement of the grinding wheel axis, taking into account the amplitude and frequency of its oscillations under the action of the emerging forces in the section plane perpendicular to the spindle axis, along which the trajectory of the wheel center movement was calculated (Fig. 8).

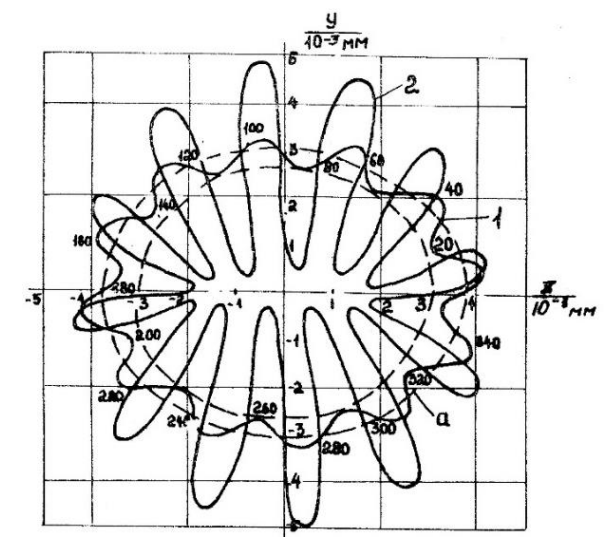

Figure 8 - Estimated trajectory of movement of the center of the circle in the plane (YOZ), for one revolution, with different processing modes (the circle is intermittent with 12 projections) 1) at $\left.V_{\partial}=0.05 \mathrm{~m} / \mathrm{s}, t=1010^{-6} \mathrm{~m} ; 2\right)$ at $V_{\partial}=0.03 \mathrm{~m} / \mathrm{s}, t=5010^{-6} \mathrm{~m}$ 
The figure shows that under the influence of the above factors, the center of the circle describes a rather complex trajectory. Moving along the ellipsoidal curve (a), it also performs sinusoidal displacements relative to this curve. With an increase in processing modes, the amplitude of sinusoidal displacements increases. The theoretically calculated trajectory is similar to the trajectory of displacement obtained experimentally (Fig. 9, 10).

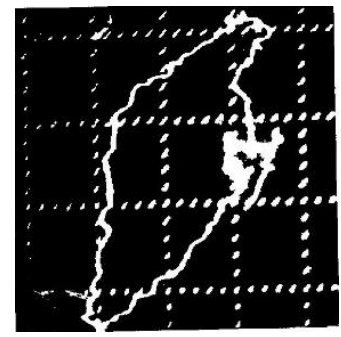

a)

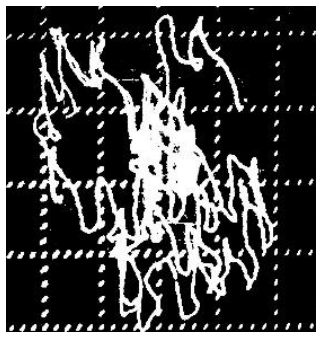

b)

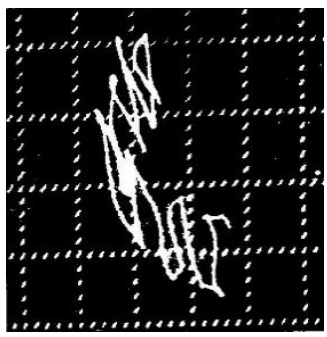

c)

Figure 9 - Oscillograms of vibration displacements of the circle center.

a) displacement during idle rotation as a result of imbalance;

b) vibration displacement when working in a circle with 10 projections;

c) part of a circle with 10 projections

During idle rotation (Fig. 9a), as a result of imbalance, the center of the circle makes ellipse-like movements. In the process of grinding, under the action of the protrusions of the circle, its center moving along a closed trajectory, simultaneously makes additional sinus-like movements relative to this trajectory (Fig. 9b, c).

Therefore, knowing the movement of the center of mass of the circle, we can proceed to the consideration of the formation of the profile of the treated surface.

Formation of a profile on the treated surface when grinding with intermittent wheels.

The shaping point of the circle, copying the movement of the center along the path $1^{\prime}$, would also sequentially occupy positions $1^{\prime}, 2^{\prime}, 3^{\prime}, 4^{\prime}$, etc., moving along the path $2^{\prime}$. But since the grinding wheel is a volumetric body with a radius $\mathrm{R}$, then the profile formed on the surface of the part will be the envelope of a family of arcs formed by the forming point of the periphery of the circle (with radius $R_{k p}$ ) and having the form (Fig. 11) 


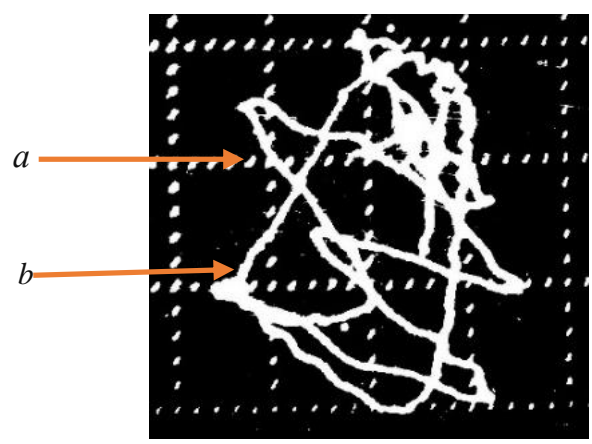

Figure 10 - The trajectory described by the center of the circle at idle rotation $(a)$, while grinding $(b)$ by a wheel with 4 protrusions

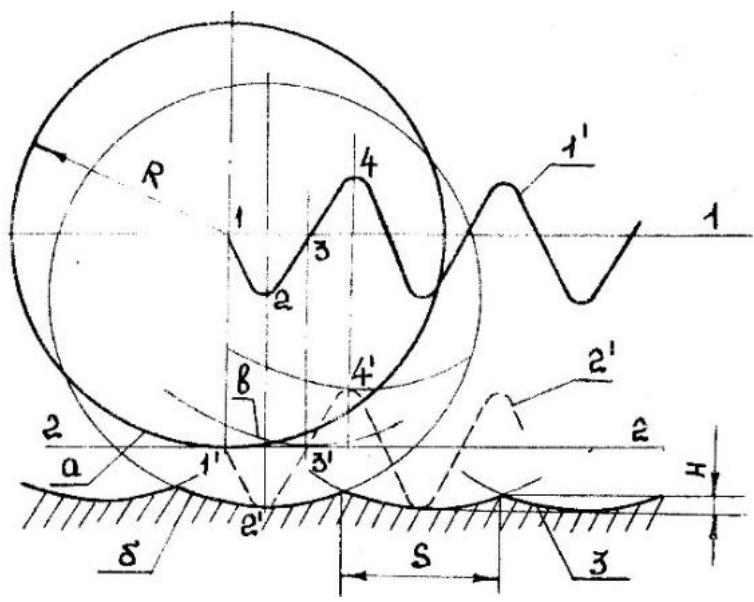

Figure 11 - Scheme of surface profile (waviness) formation

The relationship between the profile formed on the processed surface with the dynamic and kinematic parameters of the working tool can be represented as [3]

$$
Y_{в}=Y_{\text {огиб.дин. }}+Y_{\text {огиб.кин. }}
$$

where $Y_{\text {огиб.дин. }}=f_{l}\left(X_{\text {дин }}\right)$ - curve parameters associated with the dynamics of the process; 
$Y_{\text {огиб.кин. }}=f_{2}\left(X_{\text {кин }}\right)$ - the parameters of the curve associated with the kinematics of the formation of irregularities, depending on the geometric parameters of the circle (the number and length of protrusions and depressions).

The coordinates of the profile of the wavy surface during flat grinding with the periphery of the circle are determined by (f. 15),

$$
\left.\begin{array}{l}
X_{\text {дин }}=X \pm \frac{R \cdot \dot{y}}{\sqrt{(\dot{x})^{2}+(\dot{y})^{2}}} ; \\
Y_{\text {дин }}=Y \pm \frac{R \cdot \dot{x}}{\sqrt{(\dot{x})^{2}+(\dot{y})^{2}}},
\end{array}\right\}
$$

where $R$ - is the radius of the circle;

$X$ and $Y$ - are the coordinates of the center of the circle.

Substituting equations (13), taking into account the longitudinal displacement $\left(V_{\partial} \cdot t\right)$ of the part relative to the circle in (15) and making some simplifications, we obtain the parameters of the dynamic component of the profile of the wavy surface for the $i$-th harmonic formed during intermittent grinding (where $\mathrm{Y} \rightarrow \mathrm{y}, \mathrm{Z} \rightarrow \mathrm{x}$ ):

$$
\begin{aligned}
& X_{\text {дин }}=\left(A_{\mathrm{Cr}_{i}}+U_{z_{i}} \sin \omega_{\mathrm{B}_{\mathrm{i}}} t_{c}\right) \cos \omega_{0_{i}} t_{c}+V_{\mathrm{g}} t_{c}+ \\
& +\frac{R\left[\left(B_{\mathrm{CB}_{i}}+U_{y_{i}} \sin \omega_{\mathrm{B}_{i}} t_{c}\right) \omega_{\mathrm{B}_{\mathrm{i}}} \cdot \cos \omega_{0_{i}} t_{c}+U_{y_{i}} \cdot \omega_{\mathrm{B}_{i}} \cos \omega_{\mathrm{B}_{\mathrm{i}}} t_{c} \cdot \sin \omega_{0_{i}} t_{c}\right]}{V} ; \\
& Y_{\text {дй }}=\left(B_{\text {св }_{i}}+U_{y_{i}} \sin \omega_{B_{i}} t_{c}\right) \sin \omega_{0_{i}} t_{c}+ \\
& \left.+\frac{R\left[U_{z_{\mathrm{i}}} \cdot \omega_{\mathrm{B}_{\mathrm{i}}} \cos \omega_{\mathrm{B}_{\mathrm{i}}} t_{c} \cos \omega_{0_{\mathrm{i}}} t_{c}+V_{\mathrm{A}}-\left(A_{\mathrm{Cr}_{\mathrm{i}}}+U_{z_{\mathrm{i}}} \sin \omega_{\mathrm{B}_{\mathrm{i}}} t_{c}\right) \omega_{0_{\mathrm{i}}} \sin \omega_{0_{\mathrm{i}}} t_{c}\right]}{V},\right)
\end{aligned}
$$

where

$$
\begin{aligned}
& V=\sqrt{(\dot{x})^{2}+(\dot{y})^{2}} \\
& =\sqrt{\begin{array}{l}
{\left[U_{z_{i}} \cdot \omega_{\mathrm{B}_{i}} \cos \omega_{\mathrm{B}_{i}} t_{c} \cos \omega_{0_{i}} t_{c}+V_{\mathrm{A}}-\left(A_{\mathrm{Cr}_{i}}+U_{z_{i}} \sin \omega_{\mathrm{B}_{i}} t_{c}\right) \omega_{0_{i}} \sin \omega_{0_{i}} t_{c}\right]^{2}} \\
+\left[\left(B_{\mathrm{CB}_{i}}+U_{y_{i}} \sin \omega_{\mathrm{B}_{i}} t_{c}\right) \omega_{\mathrm{B}_{i}} \cdot \cos \omega_{0_{i}} t_{c}+U_{y_{i}} \cdot \omega_{\mathrm{B}_{i}} \cos \omega_{\mathrm{B}_{i}} t_{c} \cdot \sin \omega_{0_{i}} t_{c}\right]^{2}
\end{array}}
\end{aligned}
$$

The solution of the system of equations (16) makes it possible to obtain the parameters of the wavy surface $\left(X_{6}, Y_{B}\right)$ taking into account the dynamics of the cutting process.

Macroroughnesses obtained from the second $\left(Y_{\text {огиб.кин. }}=f_{2}\left(X_{\text {кии }}\right)\right)$ component in (f. 14), in fact, are quantities of the second order of smallness, in comparison with the waviness formed due to the dynamics of the process and they can be neglected. 
Based on the data calculated from dependencies (16), the trajectory of movement of the shaping point of the circle and the profile of the generated wave is constructed (Fig. 12).

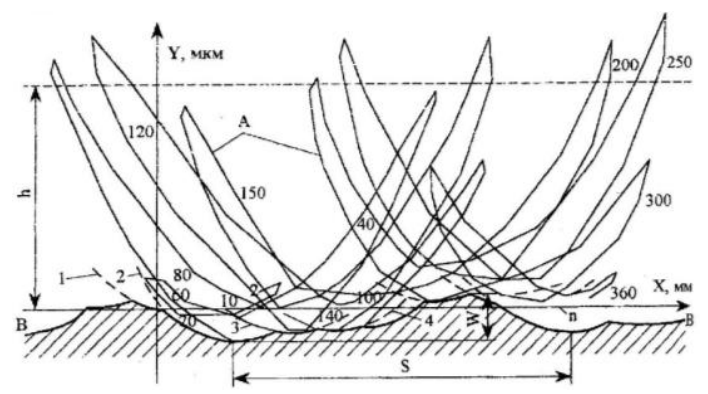

Figure 12 - The formation of waviness when machining with a broken circle (with 12 ridges). A - trajectory of the shaping point (for one revolution of the circle); $1,2,3,4 \ldots \mathrm{n}$ - the position of the forming arcs of the circle; B-B - envelope of the arc system (wave profile); $\mathrm{h}-$ is the depth of grinding

The shape-forming point of the circle, making loop-like oscillating movements, moves along the trajectory (A) repeatedly passes through the same zone of space, gradually cutting off the entire layer of metal. Arcs 1, 2, 3, $4 \ldots \mathrm{n}$ of a circle of a circle of radius $\mathrm{R}$ leave a corresponding trace on the surface of the part. The envelope curve B-B for these arcs is the profile of the waviness formed on the surface of the part.

Depending on the presence of oscillations, their amplitude and frequency (the design of the circle), the trajectory described by the shaping point of the circle and the profile of the formed waviness change somewhat (Fig. 13).

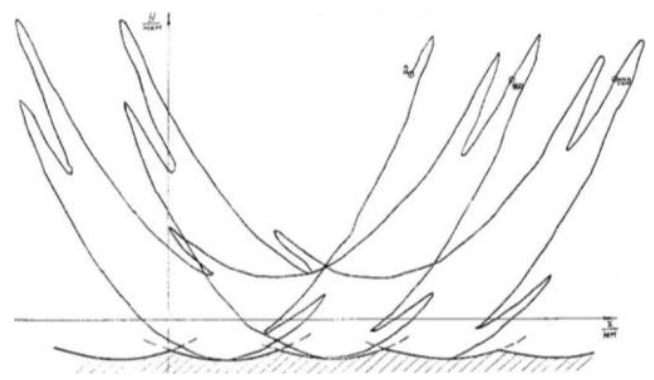

Figure 13 - The formation of waviness and the trajectory of the shaping point of the discontinuous circle (with 4 projections) 
From the analysis of the above schemes (Fig. 12, 13), one more rather significant conclusion can be drawn. As a result of the presence of such oscillating displacements, performed by an intermittent circle, at certain points in time, the forming point separates from the treated surface, and the allowance is removed in separate thin layers (portions), which will serve as one of the reasons for reducing the cutting forces, and as a result, the heat intensity of the process.

References: 1. Novoselov YU.K. Dinamika formoobrazovaniya poverkhnostey pri abrazivnoy obrabotke: Monografiya / YU. K. Novoselov. - Sevastopol': SevNTU, 2012. - 304 s 2. Suslov A.G. Nauchnyye osnovy tekhnologii mashinostroyeniya [Tekst] / A. G. Suslov, A. M. Dal'skiy. - M. : Mashinostroyeniye, 2002. - 684 s. 3. Naddachin V.B. Ispol'zovaniye vibratsiy pri preryvistom protsesse rezaniya [Tekst] / V. B. Naddachin, A. V. Babyuk // Sb.NT Obrabotka dispersnykh materialov i sred. Teoriya, issledovaniya, tekhnologii, oborudovaniye. - Odessa : NPO «Votum», 2002. - Vyp. №12. S. 126-130. 4. Biderman V.L. Teoriya mekhanicheskikh kolebaniy [Tekst] / V. L. Biderman. - M. : Vysshaya shkola, 1980. - 408 s. 5. Naddachin V.B. Vliyaniye vibratsiy na parametry kolebaniy abrazivnogo instrumenta [Tekst] / V. B. Naddachin, A. V. Balanyuk //Novyye i netraditsionnyye tekhnologii v resurso- i energosberezhenii. Sb. MNTK 19-22.09.2011 g. Odessa. - Kiyev, 2011. S. 145-147. 6. Prilutskiy V.A. Tekhnologicheskoye obespecheniye tochnosti i kachestva poverkhnostnogo sloya detaley mashin putem upravleniya periodicheskimi pogreshnostyami obrabotki [Tekst] : avtoref. dis. ... d.t.n. : 05.02.08 / V. A. Prilutskiy ; [Bryanskiy gos. tekhn. un-t] . - Bryansk, 2004. $-36 \mathrm{~s}$.

\title{
Валерій Наддачин, Одеса, Україна
}

\section{ВЗАСМОЗВ'ЯЗОК МІЖ ТЕМПЕРАТУРОЮ ОБРОБКИ ТА ПЕРЕРИВЧАСТІСТЮ ПРОЦЕСУ ШЛІФУВАННЯ}

\begin{abstract}
Анотація. У наведеній статті розглядаються питання, пов'язані з обробкою шліфувальними кругами з переривчастою робочою поверхнею $і$ їх вплив на процес шліфування. Розглянуто теоретично можсливі варіанти формування поверхні. Для вирішення иъьго завдання необхідно було на початку виявити взаємозв'язок уривчастості процесу $і$ ударного навантаження. Встановлено, щчо зі зміною кількості виступів на крузі, буде змінюватися частота удару $i$ амплітуда додаткових вимушених коливань системи. Розглянуто вплив режимів шліфування на коливальний процес. Побудована схема переміщення центру мас круга і діючих на нього сил. Наведено систему рівнянь, що описують рух осі шпинделя під дією сил різання $i$ силову неврівноваженість круга. Встановлено взаємозв'язок між частотою, амплітудою змушених коливань і переміщень осі під дією гармонійно вимушених коливань. Наведено експериментально записані осиилограми удару $і$ траєкторії переміщення иентру. На підставі переміщення формотворної точки круга встановлені параметри профілю оброблюваної поверхні. Розглянуто вплив уривчастості процесу на температуру шліфування. Експериментально доведено, щяо в прочесі обробки иліфувальними кругами з переривчастою робочою поверхнею, відбувається періодичний відрив «формотворної точки» круга від оброблюваної поверхні. В результаті такого прочесу, зняття припуску відбувається більш тонкими шарами, ніж набрана (встановлена) глибина різання. I як наслідок, зниження сил різання і температури шліфування. Тобто основним параметром (більшою мірою), що впливає на зниження температури буде вібраційний прочес, а не уривчастість прочесу різання, за період проходження западини круга.

Ключові слова: переривчасте шліфування; вібраиії при шліфуванні; траєкторія руху; удар; профіль поверхні; температури при шліфуванні.
\end{abstract}

